\title{
Między obietnicą a umową: \\ Granice zastosowania filozoficznego dyskursu o obietnicach w teorii prawa kontraktowego
}

\author{
Szymon Osmola \\ Uniwersytet Jagielloński w Krakowie \\ szosmola93@gmail.com
}

Otrzymano 20 grudnia 2017, zaakceptowano 21 stycznia 2018, opublikowano 26 kwietnia 2018.

\begin{abstract}
Abstrakt
Pojęcie obietnicy może być bardzo interesujące dla teoretyków prawa, zwłaszcza tych zajmujących się prawem kontraktowym. Celem artykułu jest przybliżenie dyskusji na temat obietnic toczonej na gruncie współczesnej filozofii analitycznej oraz przedstawienie różnych podejść do możliwości jej aplikacji na grunt teorii prawa. Wyróżnione zostaną trzy najważniejsze $\mathrm{z}$ nich: koncepcja umowy jako obietnicy (w formie zaproponowanej przez C. Frieda) oraz dwie koncepcje krytyczne - formalna oraz materialna. Koncepcja umowy jako obietnicy będzie odrzucona jako nieradząca sobie między innymi z tak zwanym paradoksem autonomii. Argumenty przedstawiane przez krytyków usposobionych formalnie zostaną uznane za zasadniczo trafne, ale niemożliwe do całkowitego zaakceptowania ze względu na cechujący je formalizm. Stanowisko reprezentowane przez niektórych zorientowanych materialnie krytyków uznane będzie za najbardziej obiecujące podejście, mimo że niekompletne i obarczone wieloma błędami.
\end{abstract}

Slowa kluczowe: obietnica; umowa; Fried; autonomia. 


\section{Wprowadzenie $^{1}$}

Pojęcie obietnicy ${ }^{2}$ cieszy się niesłabnącym zainteresowaniem filozofów przynajmniej od czasu przeprowadzonej przez D. Hume'a (2007, s. 331-337) analizy cnoty dotrzymywania przyrzeczeń ${ }^{3}$. Doniosłe znaczenie teoretyczne tego zagadnienia pokazuje chociażby to, w jak wielu kontekstach jest ono przywoływane. J. Rawls (1955) posługuje się obietnicą jako wzorcowym przykładem instytucji ufundowanej na regułach konstytuujących praktykę (practice rules). J. L. Austin (1962, s. 135) wskazuje, że obietnice stanowią jeden z przykładów aktów mowy. J. Searle (1964) z kolei wykorzystuje je, gdy próbuje przeprowadzić logicznie poprawne wyprowadzenie zdania normatywnego ze zdania deskryptywnego. Przykłady te można by mnożyć.

Coraz częściej jednak obietnice jawią się filozofom nie tylko jako coś przydatnego przy rozwiązywaniu innych, być może donioślejszych problemów, ale również jako fascynujący temat dociekań per se. Tematyką przyrzeczeń zajmują się, co zrozumiałe, głównie etycy. Syntetycznemu przedstawieniu debat toczonych na tym polu poświęcona jest część pierwsza artykułu. Ma ona jednak charakter wyłącznie wprowadzający. Głównym celem pracy jest bowiem próba wskazania, jakie znaczenie dla prawników i teoretyków prawa mogą mieć rozważania dotyczące obietnic prowadzone przez filozofów. Zarówno w potocznym myśleniu o prawie - chodzi tu przede wszystkim o prawo zobowiązań ${ }^{4}-$ jak i praktyce orzeczniczej i wielu aktach prawnych ${ }^{5}$ obecne jest przeświadczenie o silnym powiązaniu między dobrowolnym wzięciem na siebie zobowiązania w wyniku złożenia obietnicy a obowiązkami prawnymi wynikającymi z zawarcia umowy czy złożenia jednostronnego oświadczenia woli. Filozoficznym wyrazem tego przeświadczenia jest paradygmat umowy jako obietnicy (contract as promise), którego nazwa pochodzi od tytułu książki jego najważniejszego obrońcy, C. Frieda (1981). Przedstawieniu głównych tez owego nurtu poświęcona jest część druga artykułu.

\footnotetext{
${ }^{1}$ Autor pragnie wyrazić wdzięczność Wojciechowi Załuskiemu, Adamowi Dyrdzie, Bartoszowi Janikowi oraz anonimowym recenzentom Czasopisma AVANT za cenne uwagi dotyczące wcześniejszych wersji tekstu.

${ }^{2}$ Angielski termin promise można przetłumaczyć jako „obietnica” lub jako „przyrzeczenie”. Wyrazy te będą w dalszym ciągu wywodu używane zamiennie, przy czym za lepsze tłumaczenie uznać należy termin „obietnica”, z uwagi to, że termin ,przyrzeczenie” może kojarzyć się z ,przysięgą”, która jest czymś innym od obietnicy.

${ }^{3}$ Rozważania Hume'a mają znaczenie nie tylko historyczne - bardzo często odwołują się do nich chociażby przywoływani w dalszych częściach tekstu myśliciele. Samą koncepcję Hume’a w interesujący sposób analizują chociażby Baier (1985), Cohon (2008, s. 190-214) czy Pitson (1988).

${ }^{4}$ Terminy „prawo zobowiązań” oraz „prawo kontraktowe” czy „prawo umów” będą używane zamiennie, głównie ze względów stylistycznych, mimo że pierwszy ma oczywiście w języku polskim dużo szersze znaczenie, obejmujące choćby prawo deliktowe czy przepisy dotyczące bezpodstawnego wzbogacenia. Mimo że sam termin ,prawo umów” może brzmieć w uszach polskiego czytelnika nieco drażniąco, jego użycie wydaje się dla naszych celów konieczne.

${ }^{5}$ Chociażby w amerykańskiej The Restatement (Second) of the Law of Contracts, której tekst wprost odwołuje się do pojęcia obietnicy.
} 
Zwolennicy paradygmatu umowy jako obietnicy cechują się dużym optymizmem co do możliwości aplikacji osiągnięć filozofów zajmujących się obietnicami na grunt prawoznawstwa. Takie podejście często jest jednak krytykowane, a jego krytyka przybiera dwojaką postać - formalną, zasadniczo negującą możliwość zastosowania filozofii obietnic w prawie umów, uznającą pojęcia obietnicy i umowy za wzajemnie się wykluczające; oraz materialną, również zakładającą zasadniczą odmienność obietnic i umów (jednak z innych powodów), nienegującą jednak przydatności filozoficznych rozważań o obietnicach przy analizie teoretycznych podstaw prawa kontraktowego. Analizie mocnych i słabych stron obu nurtów zostaną poświęcone części trzecia i czwarta niniejszej pracy, przy czym argumenty krytyków usposobionych formalnie, pomimo uznania ich przynajmniej częściowej zasadności, zostaną odrzucone jako obarczone błędem, nomen omen, formalizmu. Podejście niektórych krytyków usposobionych materialnie zostanie natomiast uznane za bardzo obiecujące, choć wymagające staranniejszego rozwinięcia.

Zanim przejdziemy do zasadniczego toku rozważań, warto wspomnieć o jeszcze jednej kwestii. Wszystkie wymienione wyżej grupy teorii - zarówno nurt obietnicy jako umowy, jak i ujęcia krytyczne - pojęcie obietnicy uważają za w jakiś sposób kluczowe. Wynika to zapewne z wagi, jaką przywiązują one do potocznych intuicji związanych z prawem zobowiązań oraz do języka aktów prawnych i twierdzeń doktryny. Jedną z konsekwencji takiego stanu rzeczy jest twierdzenie o odrębności prawa umów względem innych gałęzi prawa - niezależnie od poglądów dotyczących rzeczywistego znaczenia przyrzeczeń w prawie. Tymczasem istnieją grupy teorii, o wiele radykalniejszych w swojej krytyce, które kwestionują, bezpośrednio lub pośrednio, nawet to założenie. Najbardziej jaskrawym przykładem takiego stanowiska są koncepcje teoretyków takich jak P. Atiyah (1979, 1983) czy G. Gilmore (1995), postulujących ,śmierć umowy” (zgodnie z tytułem najważniejszej książki tego drugiego) i sugerujących możliwość zredukowania prawa umów do innych gałęzi prawa, głównie prawa deliktowego. Podobną, choć nieco odmienną ścieżką podążają niektórzy przedstawiciele nurtu Critical Legal Studies (np. Kennedy, 1976), którzy prawo umów postrzegają jako instrument realizujący interesy określonej grupy społecznej, w związku z czym uznają je za pozbawione odpowiedniej legitymacji. Drugą wielką grupą tego typu teorii są koncepcje należące do nurtu ekonomicznej analizy prawa (por. np. Posner, 2011). Ich przedstawiciele najczęściej nie wypowiadają się bezpośrednio o wzajemnych stosunkach pojęć obietnicy i umowy, ponieważ tego typu rozważania uważają po prostu za zbędne. Przyjęte przez nich założenia metodologiczne, oparte na postulacie maksymalizacji użyteczności, niezależnie od dziedziny prawa, jaką akurat się zajmują, a także wynikające z tego postulatu skupienie się raczej na przewidywaniu wyników poszczególnych spraw oraz formułowaniu postulatów dotyczących tak zwanych domyślnych reguł prawnych (default rules) sprawiają, że potencjalne wykorzystanie przez prawników osiągnięć filozofów zajmujących się obietnicami jest według nich pozbawione jakiegokolwiek znaczenia praktycznego i teoretycznego (zob. np. Craswell, 1989, 2001; Kraus, 2002, 2009). 
Zarówno teorie wieszczące ,śmierć umowy”, jak i teorie ekonomiczne nie będą przedmiotem dalszych analiz. Z przynajmniej trzech powodów. Pierwszym jest to, że ich analiza wymagałaby odrębnego opracowania. Drugim, być może najważniejszym, jest silne przekonanie o znaczeniu wspomnianych już potocznych intuicji ${ }^{6}$ i twierdzeń doktryny w budowaniu wartościowej teorii prawa. Powodem trzecim jest możliwość, przynajmniej teoretyczna, pogodzenia, z uwagi na odmienność przyjmowanych założeń metodologicznych, koncepcji kładących nacisk na znaczenie filozofii obietnic dla teorii prawa kontraktowego z koncepcjami uznającymi to znaczenie za niewielkie - a przynajmniej z niektórymi teoriami należącymi do nurtu ekonomicznej analizy prawa (por. Kraus, 2001). Poczyniwszy te zastrzeżenia, możemy przejść do kwestii tego, jakimi zagadnieniami w ogóle zajmują się filozofowie badający fenomen obietnic.

\section{Ujęcie obietnic w filozofii analitycznej}

Zagadnienie obietnic w szeroko pojętej współczesnej filozofii analitycznej jest na tyle rozbudowane, że jakakolwiek próba jego wyczerpującego przedstawienia byłaby zadaniem karkołomnym. O wiele lepszą strategią wydaje się wyodrębnienie bardziej szczegółowych wątków, jakimi zajmują się filozofowie pochylający się nad interesującym nas tematem. Wątki te można sprowadzić za Sheinmanem (2011, s. 8-35) do kilkunastu wzajemnie ze sobą powiązanych pytań. Brzmią one następująco:

(i) Czym jest (pojedyncza) obietnica?

(ii) Czy obietnice - a zatem również będące konsekwencją ich złożenia racje do działania, motywy i zobowiązania - ze swojej istoty zakładają istnienie wcześniejszej praktyki obiecywania, tak że niemożliwym jest złożenie obietnicy - czyli również stworzenie sobie racji do działania, motywu czy zobowiązania - w inny sposób niż przywołanie takiej wcześniej istniejącej praktyki?

(iii) Czy praktyka, w ramach której składana jest dana obietnica, jest w stosunku do tej obietnicy pojęciem pierwotnym, w kontekście wyjaśnienia fenomenu obietnic?

(iv) Czy istnieje generalny moralny obowiązek dotrzymywania złożonych obietnic?

(v) Kiedy, i z jakich powodów, mamy moralny obowiązek dotrzymywania złożonych obietnic?

(vi) Jaka jest wartość obiecywania?

(vii) Czy wtedy, kiedy mamy moralny obowiązek dotrzymania złożonej obietnicy, wywodzi się on (wyłącznie) z wartości, jakie niesie za sobą (rzeczywista bądź hipotetyczna) praktyka obiecywania?

\footnotetext{
${ }^{6}$ Twierdzenie to jest bliskie metodologicznemu podejściu do teorii prawa zaprezentowanej przez S. Shapiro (2011, s. 13-16), który proponuje opierać teoretyczne rozważania o prawie na powszechnie uznawanych truizmach go dotyczących.
} 
(viii) Jakie reguły czy zasady obiecywania powinniśmy, jako grupa społeczna, zaakceptować jako powszechne standardy postępowania?

(ix) Dlaczego mamy właśnie takie, a nie inne praktyki obiecywania?

(x) Jaka jest wzajemna relacja obietnic i porozumień?

(xi) Jaka jest wzajemna relacja umów i obietnic?

(xii) Jakie reguły czy zasady zawierania umów powinniśmy zawrzeć w naszym systemie prawnym?

Narażając się na zarzut zbytniego uproszczenia, można stwierdzić, że każdy filozof zajmujący się zagadnieniem obietnic próbuje odpowiedzieć na wszystkie lub przynajmniej niektóre z powyższych pytań. Odpowiedzi te są oczywiście rozmaite, różna jest też waga, jaką przywiązuje się do poszczególnych pytań. Z punktu widzenia celów niniejszej pracy najbardziej interesujące jest oczywiście pytanie (xi). Pytanie (x) będzie ważne w kontekście rozważań nad formalnie usposobionymi krytykami paradygmatu umowy jako obietnicy. Mniej istotne będzie natomiast pytanie (ii), głównie ze względu na niejasność i różnorodność pojęcia konwencji, jakie często jest w tym kontekście przywoływane (co, zdaniem niektórych, czyni spory o pierwotność pojęć pojedynczej obietnicy czy praktyki obiecywania sporami jałowymi (zob. Shiffrin, 2008); nie zmienia to jednak faktu, że samo pojęcie konwencji i jego związków z pojęciem prawa jest dla teoretyków prawa niezwykle ciekawym tematem analiz - w tej kwestii zob. zwłaszcza Dyrda (2013). W naturalny sposób pociąga to za sobą mniejszą wagę pytań (iii) i (vii). Pytanie (ix) jest ciekawe z punktu widzenia filozofów zorientowanych ,genealogicznie”, to jest szukających genezy danego zjawiska w celu jego wyjaśnienia (zob. zwłaszcza Atiyah, 1979; Ibbetson, 1999; Swain, 2013), nie jest jednak aż tak ważne w przypadku nastawienia bardziej systematycznego, jak ma to miejsce w tej pracy. Pytania (iv), (v) i (vi), które uznać można za różne sformułowania tego samego pytania, będą posiadały dla nas dużą wartość - zwłaszcza w kształcie nadanym w pytaniu (vi) - w kontekście materialnej krytyki paradygmatu umowy jako obietnicy. Dalej, odpowiedź na pytanie (i), bardzo abstrakcyjne, może posiadać dla nas wartość praktyczną o tyle, o ile będziemy w stanie powiązać ją z odpowiedzią na pytanie (vi). Wreszcie, odpowiedź na pytanie (xii), niewątpliwie interesujące z punktu widzenia filozofii prawa, jest obiektem badań wspomnianych wcześniej zwolenników ekonomicznej analizy prawa umów - nie będzie więc mogło, podobnie jak ściśle z nim związane pytanie (viii), otrzymać tu uwagi, na jaką zasługuje.

Nie jest oczywiście tak, że filozofowie prawa są jedynie biernymi odbiorcami treści dostarczanych przez filozofów zajmujących się obietnicami. Często to właśnie prawnicy i teoretycy prawa, tacy jak chociażby N. MacCormick (1972), J. Raz (1972, 1977), S. Shiffrin (2008) czy D. Markovits (2011), są autorami najciekawszych filozoficznych koncepcji dotyczących przyrzeczeń. Niektóre z nich zostaną przywołane w dalszej części pracy. Na razie przyjrzyjmy się jednak dokładniej koncepcji, która, choć sama nie wnosi wiele nowego do filozofii obietnic jako takiej, to czerpie z niej pełnymi garściami a przynajmniej tak deklarują jej zwolennicy. 


\section{Umowa jako obietnica}

Jak już była o tym mowa, koncepcja umowy jako obietnicy została najpełniej wyrażona na początku lat 80 . XX wieku przez C. Frieda, a często jest wręcz utożsamiana z jego nazwiskiem. W zamierzeniu miała stanowić ona odpowiedź na wieszczące „śmierć umowy” teorie w stylu Atiyaha, Gilmore'a czy Kennedy’ego, postulując powrót do klasycznie rozumianej zasady swobody umów, której początków dopatrywał się Fried między innymi w dziełach Hume’a (Fried, 1981, s. 1-3); w bardziej współczesnym sformułowaniu teoria umowy jako obietnicy stawia się natomiast w opozycji do dominujących obecnie koncepcji z zakresu ekonomicznej analizy prawa (Fried, 2014, s. 21). Dzięki pracom J. Krausa $(2001,2002)$ w literaturze dotyczącej filozofii prawa umów zwykło się dokonywać rozróżnienia pomiędzy teoriami kładącymi nacisk na autonomię jednostek (autonomy theories) a teoriami kładącymi nacisk na efektywność (efficiency theories). Koncepcję umowy jako obietnicy należy uznać za koronny przykład tej pierwszej ${ }^{7}$. Rozróżnienie to jest ważne, ponieważ zarówno dalszy rozwój, jak i krytyka rozważań Frieda w dużej mierze odnosi się właśnie do tego, jaką konkretnie koncepcję autonomii przyjmuje on i jego zwolennicy. Zanim jednak zajmiemy się tym zagadnieniem, zobaczmy, jak wygląda teoria obietnicy jako umowy w jej oryginalnym sformułowaniu.

Zasada obietnicy (the promise principle), którą Fried uznaje za moralną podstawę całego prawa umów, sprowadza się w jego rozumieniu do tego, że ludzie mają możliwość dobrowolnego nakładania na siebie zobowiązań moralnych, które wcześniej w ogóle nie istniały (Fried, 1981, s. 1). Prawo umów jest więc odrębną gałęzią prawa, której istnienie uzasadnione jest tym, iż jako jedyna zajmuje się egzekwowaniem specyficznego typu zobowiązań, bardzo ważnego z punktu widzenia przyjętego przez Frieda systemu etycznego opartego na filozofii Kanta, z jego przywiązaniem do takich oświeceniowych wartości jak autonomia oraz praktyczna racjonalność jednostek (Fried, 1981, s. 17). „Obowiązek dotrzymania obietnicy”, twierdzi Fried (1981), „nie bierze się z rozważań dotyczących użyteczności, ale z szacunku do indywidualnej autonomii i zaufania” (s. 16). System prawny jako całość, wraz z jego zapleczem instytucjonalnym służącym do egzekwowania rozmaitych obowiązków, często przy pomocy przymusu, posiada społeczną legitymizację, gdyż realizuje cele, które przynajmniej część członków danego społeczeństwa uznaje za wartościowe. Prawo umów posiada społeczną legitymację, bo w ogromnej mierze przyczynia się do pełniejszej realizacji zasad autonomii oraz wzajemnego szacunku - a jego odrębność, wynikająca z ufundowania go na zasadzie obietnicy, tak często przez Frieda podkreślana, jest usprawiedliwiona szczególną wartością owych zasad dla funkcjonowania zarówno całego społeczeństwa, jak i poszczególnych jednostek.

\footnotetext{
${ }^{7}$ Zdarza się, że są one ze sobą utożsamiane, co wydaje się podejściem nie do końca poprawnym, biorąc pod uwagę fakt występowania innych teorii kładących nacisk na autonomię, nienależących jednak do odmian teorii umowy jako obietnicy (zob. np. Raz, 1972, 1977; Scanlon, 1998, 2001).
} 
Przywiązanie do tezy o odrębności prawa umów jako w całości opartego na zasadzie obietnicy rodzi zasadnicze problemy, które ujawniają się, kiedy Fried przechodzi do analizy poszczególnych instytucji prawnych rozpatrywanych w kontekście swoich ogólnych założeń. Jako że ta część wywodu Frieda jest mocno osadzona w tradycji common law, w wielu miejscach zasadniczo odmiennej od kontynentalnych systemów prawnych, nie ma sensu szczegółowo jej tutaj przedstawiać ${ }^{8}$. Ograniczymy się zatem do jednej rozpatrywanej przez Frieda doktryny, której analiza wzbudziła najwięcej kontrowersji - tak zwanej consideration doctrine. Jej treść sprowadza się do tego, że egzekucji podlegają jedynie te umowy, które były, w ten czy inny sposób, negocjowane (contracts which was bargained for). Tymczasem, na co zwraca uwagę większość komentatorów, na gruncie teorii Frieda egzekucji powinny podlegać w zasadzie wszystkie umowy ${ }^{9}$. Fried konkluduje więc, iż cała consideration doctrine jest aberracją, której występowanie w zasadzie nie ma żadnego racjonalnego uzasadnienia (Fried, 1981, s. 28-39). W przypadku innych instytucji, które są w jakiś sposób niezgodne z zasadą obietnicy - jak na przykład instytucji promissory estoppel ${ }^{10}$ - twierdzi zaś po prostu, że nie są one częścią prawa umów, a swoją legitymację czerpią z innych zasad moralnych czy prawnych - w tym przypadku z zasady nakazującej czynić zadość uzasadnionym oczekiwaniom innych. Podobną ścieżką podąża S. Shiffrin, jedna z najwybitniejszych przedstawicielek teorii autonomii, która w słynnym artykule dotyczącym „dywergencji” umów i obietnic (Shiffrin, 2007) wskazuje na „rozjeżdżanie się" moralnych podstaw prawa kontraktowego - a więc zasady obietnicy z praktyką prawniczą, a często również z teorią prawa umów, co jest widoczne chociażby w bardzo popularnej na gruncie ekonomicznej analizy prawa koncepcji efektywnego złamania umowy (efficient breach).

Już z powyższego krótkiego streszczenia wynika podstawowy zarzut, jaki postawić można koncepcji umowy jako obietnicy, przynajmniej w jej wczesnej wersji zaproponowanej przez Frieda, z jej naciskiem na odrębność prawa umów i jednolitość stojących u jego podstaw zasad - teoria ta nie dostarcza sensownego kryterium pozwalającego na określenie, które obietnice nadają się do prawnej egzekucji, a które powinny pozostać poza reżimem prawnym. Twierdzenie bowiem, że egzekwowane powinny być wszystkie obietnice

\footnotetext{
${ }^{8}$ Rodzi to oczywiście pytania o sens czy nawet samą możliwość stworzenia uniwersalnej teorii prawa umów, która byłaby niezależna od jakiegokolwiek konkretnego systemu prawnego. Zostawiając tę kwestię otwartą, można chyba jednak uznać, że teoria taka jest co do zasady, na odpowiednim poziomie ogólności, możliwa.

${ }^{9} \mathrm{Z}$ oczywistymi wyjątkami dotyczącymi, ogólnie rzecz biorąc, różnych błędów oświadczeń woli czy umów zawartych pod przymusem (por. Fried, 1981, s. 37-38). Można jednak twierdzić, iż w tego typu sytuacjach w ogóle nie doszło do zawarcia umowy.

${ }^{10}$ Odpowiadająca łacińskiej paremii venire contra factum proprium nemini licet. Zasada ta sprowadza się do tego, by w pewnych sytuacjach nie wiązać powstania zobowiązania prawnego z intencją leżącą po stronie danego podmiotu, ale wywodzić je z samego zachowania podmiotu w pewnych okolicznościach, co normalnie wiąże się z powstaniem takiego zobowiązania. Przykładowo, kierowca wjeżdżający na płatny parking, bez intencji opłacenia miejsca postojowego, a nawet otwarcie twierdzący, że takiej opłaty nie uiści, i tak będzie zobowiązany do poniesienia odpowiednich kosztów. Istnienie tej instytucji uzasadnione jest przede wszystkim bezpieczeństwem i trwałością obrotu prawnego.
} 
bez wyjątku, jest wybitnie nieintuicyjne. Można też wysunąć wobec niego następujący kontrargument: co z takimi obietnicami, których autorzy zaznaczyli, iż nie życzą sobie, aby podlegały one egzekucji? Skoro egzekucji na drodze prawnej powinny podlegać wszystkie obietnice bez wyjątku, to także tego typu. Ich egzekucja przeczyłaby jednak autonomii podmiotu i jego rzeczywistej intencji, co również jest nie do przyjęcia na gruncie teorii Frieda ${ }^{11}$. Paradoks ten nazwać można paradoksem autonomii i stanowi on - obok przedstawionych w kolejnych punktach pracy zarzutów - najsilniejszy argument przeciwko paradygmatowi umowy jako obietnicy.

Próbę jego rozwiązania proponuje J. Kraus (2009). Próba ta została podjęta w związku ze wspomnianą potrzebą doprecyzowania, jaką konkretnie koncepcję autonomii przyjmuje Fried. Autor odwołuje się do zaproponowanej przez J. Feinberga koncepcji autonomii jako osobistej suwerenności (sovereignty conception of autonomy), zgodnie z którą składający obietnice powinni odpowiadać za ich dotrzymywanie, co wynikać ma z szacunku dla ich prawa do nakładania na siebie moralnych zobowiązań w takiej formie, jaką uważają za najbardziej odpowiednią (Kraus, 2009, s. 1617). Koncepcja taka, zdaniem Krausa, najlepiej odpowiada przyjmowanym przez Frieda, często niewysłowionym, założeniom i pozwala utrzymać nienaruszonym trzon jego teorii. Zarazem wymaga ona jednak odejścia od koncepcji tak zwanej „silnej korespondencji” między obietnicami a umowami (uznawanej przez Frieda czy Shiffrin) oraz związanej z nią koncepcji subiektywnej intencji, a przyjęcia koncepcji obiektywnego oświadczenia woli. Szczegóły tych zarzutów nie są w tym momencie istotne, warto jednak podkreślić, że sam Fried, zapewne częściowo pod ich wpływem, w późniejszych pracach $(2007,2014)$ znacznie złagodził głoszone wcześniej tezy. Odmienne próby poradzenia sobie z tym podstawowym problemem - problemem doboru kryteriów odróżniających obietnice podlegające i niepodlegające egzekucji - zaproponowali J. Raz (1977) i T. Scanlon (2001). Jednakże wszyscy zwolennicy teorii autonomii - również w jej zrewidowanej czy łagodniejszej, to jest odrzucającej ,silną korespondencję" wersji - zasadniczo zgadzają się co do tego, że zasada obietnicy, w takiej czy innej formie, a czasami przy wsparciu dodatkowych zasad moralnych, stanowi odpowiednią podstawę legitymizującą prawo umów. Twierdzenie to poddane zostało krytyce ze strony teoretyków uważających, że pojęcia obietnicy i umowy są wzajemnie się wykluczające, daremnym jest więc poszukiwanie jakichkolwiek związków między nimi. Jest to wspomniana we wprowadzeniu grupa krytyków przyjmujących formalne podejście.

\section{Umowa jako obietnica - krytyka formalna}

Rozważmy przykład prostej umowy, wzorowany na przykładzie M. Gilbert (1993): A zobowiązuje się skosić trawnik B, w zamian za co B zobowiązuje się wyprowadzić na spacer psa A. Choć analiza Gilbert dotyczy głównie kwestii, czy porozumienie (agreement) możemy uznać za wymianę obietnic, to wydaje się, że rozważania te równie dobrze można

${ }^{11}$ Ze względu na jej silne związki z popularną - przynajmniej w amerykańskiej nauce prawa - teorią woli. 
zastosować do kwestii wzajemnych relacji obietnic i umów ${ }^{12}$. Tam, gdzie Gilbert mówi o porozumieniu, my będziemy mówić o umowie. Zacznijmy od trzech wyróżnionych przez nią warunków, które zdajemy się intuicyjnie uznawać za należące do istoty umów: (i) warunku powstania zobowiązania (performance criterion), (ii) warunku symultaniczności zobowiązań (simultaneity criterion) oraz (iii) warunku ich współzależności (interdependence criterion) (Gilbert, 1993, s. 629-932). Warunek (i) mówi po prostu, że w wyniku zawarcia porozumienia (umowy) po obu stronach pojawi się obowiązek określonego działania lub zaniechania. Warunek (ii) stwierdza, że zobowiązania te powstają w tym samym momencie czasowym, natomiast warunek (iii), że zarówno samo powstanie, jak i trwanie obu tych zobowiązań są ze sobą w jakiś sposób związane - powstanie i trwanie jednego zależne jest od powstania i trwania drugiego, i vice versa. Aby przekonać się, czy umowa może być uznana za wymianę obietnic, musimy sprawdzić, czy spełnia ona powyższe warunki.

Warunek (i) możemy przy tym uznać za spełniony na mocy samej definicji; do istoty pojęcia obietnicy należy bowiem wykreowanie przez nią zobowiązania - moralnego czy jakiegokolwiek innego. O wiele gorzej jest ze spełnieniem warunków symultaniczności i współzależności. Trudności, jakie stwarzają te warunki, najlepiej pokazać poprzez próbę uściślenia tego, w jaki sposób możemy uszczegółowić postanowienia wspomnianej umowy. Oto kilka z zaproponowanych przez Gilbert (1993, s. 635-643) możliwości, wyrażonych w formie hipotetycznej wymiany obietnic przez A i B:

(1) A: Obiecuję skosić twój trawnik.

B: Obiecuję wyprowadzić na spacer twojego psa.

(2) A: Pod warunkiem, że (bezwarunkowo) obiecasz wyprowadzić na spacer mojego psa, obiecuję skosić twój trawnik.

B: Pod warunkiem, że (bezwarunkowo) obiecasz skosić mój trawnik, obiecuję wyprowadzić na spacer twojego psa.

(3) A: Obiecuję, że skoszę twój trawnik, jeżeli ty obiecasz, że wyprowadzisz na spacer mojego psa.

B: Pod warunkiem, że obiecasz mi to: skosisz mój trawnik, jeżeli obiecam, że wyprowadzę na spacer twojego psa - obiecuję, że wyprowadzę na spacer twojego psa.

(4) A: Obiecuję: skoszę twój trawnik, jeżeli obiecasz mi to: wyprowadzę na spacer twojego psa, jeżeli skosisz mój trawnik.

B: Pod warunkiem, że obiecasz mi to: skosisz mój trawnik, jeżeli obiecam to: wyprowadzę na spacer twojego psa, jeżeli skosisz mój trawnik - obiecuję: wyprowadzę twojego psa na spacer, jeżeli skosisz mój trawnik.

\footnotetext{
${ }^{12}$ Por. pytanie (x) wyróżnione w części pierwszej artykułu.
} 
(5) A: Pod warunkiem, że złożysz identyczną, warunkową obietnicę, jak ta, którą teraz składam, obiecuję wypełnić swoją rolę w następującej parze działań: A kosi trawnik B, a B wyprowadza na spacer psa A.

B składa identyczną obietnicę.

Jak łatwo zauważyć, w sytuacji (1) nie zostaje spełniony ani warunek symultaniczności, ani warunek współzależności - zobowiązanie A powstaje przed zobowiązaniem B. Kolejne, coraz bardziej wyrafinowane (i mniej intuicyjne) przykłady ${ }^{13}$ są próbami zmiany takiego stanu rzeczy. I chociaż wydaje się, że radzą sobie one z warunkiem symultaniczności - płacąc jednak za to wysoką cenę, jaką jest niepewność, jakie właściwie zobowiązania rodzą się po obu stronach (i w którym momencie) - to żaden $\mathrm{z}$ nich nie oddaje W sposób zgodny z naszymi intuicjami warunku współzależności. W konsekwencji Gilbert uznaje, że porozumień (a więc również umów) nie można uznać za wymianę wzajemnych przyrzeczeń, ale należy zaliczyć je do jakiejś innej kategorii, przy czym ona sama za kategorię taką uznaje wspólne zobowiązania (joint commitments) - koncepcję rozwiniętą przez nią szerzej w innym miejscu (Gilbert, 1993, s. 647-649; 2014).

Tego typu argumenty wysuwają również inni teoretycy, w tym również ci, dla których umowy stanowią główny przedmiot zainteresowania. Przykładowo, J. Penner (1996) podobnie uznaje, iż umowy należy rozpatrywać raczej w kategoriach porozumień niż obietnic, gdyż pojęcie porozumienia sugeruje pewne wspólne przedsięwzięcie, kooperację czy wzajemne świadczenia pomiędzy stronami, co o wiele lepiej koresponduje z potocznym rozumieniem umów niż pojęcie obietnicy, w którym stosunkowo niewielką uwagę poświęca się drugiej, „biernej” stronie (Penner, 1996, s. 333). Penner wyodrębnia przy tym trzy podstawowe typy porozumień: porozumienia wzajemne (mutual agreements), porozumienia wzajemnie zobowiązujące (mutual obligatory agreements) oraz transakcje (bargains), w zależności od typów relacji międzyludzkich za nimi stojących. Umowom, które z założenia służyć mają zaspokajaniu osobistych interesów stron, bez specjalnego oglądania się na interesy drugiej strony, siłą rzeczy najbliżej jest do ostatniego typu porozumień, co nie zmienia jednak faktu, że czasem mogą one realizować również cele dwóch pozostałych typów porozumień (Penner, 1996, s. 338). Nieco inaczej sprawę ujmuje R. Barnett (1986, 2014). Zamiast tak czy inaczej rozumianego porozumienia, proponuje on rozpatrywać umowy w kategorii zgody (consent), rozumianej jako zgoda na stosowanie się do reguł rządzących systemem prawnym, w ramach którego umowa jest zawierana, a więc również na poniesienie określonych konsekwencji jej niedotrzymania - jest to coś o wiele bardziej skomplikowanego niż prosta obietnica (Barnett, 2014, s. 48). Zaliczenie umów jako realizujących tak rozumiane pojęcie zgody pozwala, zdaniem Barnetta, nie tylko o wiele lepiej zrozumieć sam fenomen umowy, ale również efektywniej i z większą

${ }^{13}$ Gilbert wymienia ich jeszcze drugie tyle. 
pewnością rozwiązać problemy stojące zarówno przed teorią, jak i praktyką prawa kontraktowego, a także daje lepsze perspektywy rozwiązania problemów, jakie w przyszłości mogą się na ich gruncie pojawić (1986, s. 270) ${ }^{14}$.

Formalną krytykę paradygmatu umowy jako obietnicy należy zasadniczo uznać za trafną. Można oczywiście krytykować niektóre ze wspomnianych wyżej założeń, jak chociażby wyróżnione przez Gilbert warunki symultaniczności oraz współzależności zobowiązań. Przykładowo, w polskim prawie cywilnym wyróżnia się specjalny typ umów: umowy wzajemne; kodeks cywilny definiuje je jako umowy, w których obie strony zobowiązują się w taki sposób, że świadczenie jednej z nich ma być odpowiednikiem świadczenia drugiej (art. 487 § 2 kc). Ktoś mógłby argumentować, że skoro ustawodawca zdecydował się na wyróżnienie specjalnej kategorii umów wzajemnych, to muszą istnieć również umowy wzajemnymi niebędące, a więc takie, które nie muszą spełniać nie tylko warunku współzależności, ale nawet symultaniczności ${ }^{15}$. Jednak nawet gdyby uznać tego typu argument za trafny ${ }^{16}$, to trzeba powiedzieć, iż nie rozwiązuje on zasadniczego problemu: umowy wzajemne - a więc takie, które spełniają warunek symultaniczności oraz współzależności - nie dość, że istnieją, to jeszcze stanowią zdecydowaną większość występujących w polskim systemie prawnym umów ${ }^{17}$. Koncepcja umowy jako wymiany obietnic, nawet jeżeli miałaby zastosowanie do pozostałych typów umów, nie byłaby w stanie w sposób prawidłowy przeanalizować podstawowego przedmiotu swojego zainteresowania, co czyniłoby ją niemal zupełnie nieprzydatną. Mocy krytyki formalnej nie osłabia również potencjalna słabość własnych pozytywnych rozwiązań proponowanych przez jej przedstawicieli. Nawet jeżeli uznajemy pojęcia takie jak wspólne przedsięwzięcia, transakcje, zgoda czy dobra wiara (w technicznym znaczeniu tych terminów) za niejasne bądź nieprzekonujące, w niczym nie umniejsza to poprawności formalnych argumentów przeciwko koncepcji umowy jako obietnicy.

Czy jesteśmy wobec tego skazani na porzucenie jakichkolwiek rozważań na temat możliwych aplikacji osiągnięć filozofów zajmujących się obietnicami do filozofii prawa, a w szczególności prawa kontraktowego? Twierdząca odpowiedź na to pytanie wydaje się przedwczesna, a jej przyjęcie byłoby objawem sztywnego formalizmu, który zasadnie można uznać za stanowisko nieuprawnione nie tylko w kontekście stosowania prawa rozumianego jako „stosowanie prawa ściśle według zapisów tekstu prawnego, nawet wtedy, gdy osiągane rozstrzygnięcie jest niesprawiedliwe lub sprzeczne ze zdrowym

\footnotetext{
${ }^{14}$ Nieco podobną koncepcję - odwołującą się do pojęcia „dobrej wiary” - rozwija D. Markovits (2004, 2006, 2011).

${ }^{15} \mathrm{Na}$ przykład umowa darowizny - typ umowy jednostronnie zobowiązującej - scharakteryzowana w polskim kodeksie cywilnym. Dla uproszczenia pominięto powyżej jednostronne czynności prawne.

${ }^{16}$ Może on budzić wątpliwości choćby z uwagi na brak wymaganej od teorii prawa uniwersalności - jest bowiem
ograniczony tylko do jednego systemu prawnego.

${ }^{17}$ Jeszcze inną kwestią jest możliwość istnienia „pozaprawnych umów”, które, co do zasady, wydają się być zasadniczo poprawną kategorią na gruncie prawa polskiego, choć na gruncie prawa anglosaskiego już niekoniecznie. To już jednak temat na odrębne rozważania.
} 
rozsądkiem" (Matczak, 2007, s. 9) - ale również na gruncie dyskursu teoretycznoprawnego ${ }^{18}$. Stanowisko formalistyczne wymagałoby odejścia od powszechnie przyjmowanych intuicji i potencjalnie mogłoby prowadzić do rezultatów sprzecznych ze zdrowym rozsądkiem - co oczywiście nie przemawiałoby jeszcze za koniecznością jego odrzucenia, gdyby nie fakt, że usposobieni formalnie krytycy nie proponują w zamian rozwiązań, które uznać można by za satysfakcjonujące.

Obietnice i umowy są odmiennymi fenomenami - tu należy zgodzić się z formalną krytyką paradygmatu umowy jako obietnicy. Nie da się jednak zaprzeczyć, że są to fenomeny dość podobne, dotyczące dobrowolnie zaciąganych zobowiązań - prawnych i moralnych. Jak zatem pogodzić nasze intuicje dotyczące silnego powiązania obietnic i umów, uznając zarazem przynajmniej częściową zasadność krytyki wysuniętej przez Gilbert i pozostałych? Rozwiązanie stanowić może tutaj wspomniane już rozróżnienie na formalną i materialną krytykę paradygmatu umowy jako obietnicy. Jest ono bliskie dokonanemu przez M. Pratta rozróżnieniu na dwa możliwe rozumienia wzajemnych powiązań między umowami a obietnicami. Pisze on tak:

Umowy i obietnice są powszechnie uznawane za pojęcia pokrewne. Rzeczywiście, prawnicza ortodoksja utrzymuje, że odpowiedzialność umowna jest oparta właśnie na obietnicy. Należy wyróżnić dwa sensy, w których zdanie to może być prawdziwe. Może być ono prawdziwe w sensie materialnym (justificatory), jeżeli zobowiązania wynikające z umów są uzasadnione racjami takimi samymi jak moralne zobowiązania wynikające ze złożonych obietnic. Może być ono prawdziwe również w sensie formalnym, jeżeli umowy są konstytuowane przez obietnice bądź wymiany obietnic. (Pratt, 2007, s. 531; tłumaczenie moje) ${ }^{19}$

I choć dalszy ciąg rozumowania Pratta jest wysoce kontrowersyjny - twierdzi on bowiem, że obietnicom jako takim nie przysługuje żadna moc normatywna, w związku z czym nie mogą one stanowić (jakkolwiek rozumianej) podstawy dla prawa umów z jego rozbudowanym systemem egzekucji zobowiązań prawnych - to wprowadzone przezeń rozróżnienie należy uznać na niezwykle przydatne. W pewnym sensie pozwala ono jednocześnie mieć ciastko i zjeść ciastko: brak ścisłego związku pomiędzy formalnym a materialnym uzasadnieniem prawa umów powoduje, że, nawet uznając za zasadne argumenty formalistów, w dalszym ciągu możemy próbować odwoływać do pojęcia obietnicy w celu lepszego zrozumienia fenomenów właściwych prawu zobowiązań. Oczywiście samo to nie świadczy jeszcze o tym, że odwołania te będą zasadne. Tym tropem podąża jednak bardzo wielu

\footnotetext{
${ }^{18}$ Przy czym nie należy utożsamiać formalizmu - zjawiska negatywnego - z akceptacją formalności prawa, przejawiającej się chociażby w formułowaniu generalnych reguł czy stawianiu odpowiednich wymagań odnośnie, na przykład formy niektórych czynności prawnych (por. Matczak, 2007, s. 20, 82-110).

19 „Contracts and promises are widely regarded as cognate ideas. Indeed legal orthodoxy has it that contractual liability is promissory. A distinction needs to be drawn between two senses in which this might be true. It may be true in a justificatory sense if contractual obligations are justified by reasons that are the same as or analogous to those that justify the moral obligations of promises. Or it may be true in a formal sense, if contracts are constituted by promises or exchanges of promises."
} 
teoretyków, a jego początków można dopatrywać się w klasycznym już artykule N. MacCormicka Voluntary Obligations and Normative Powers (1972), któremu warto poświęcić w tym miejscu chwilę uwagi.

\section{Umowa jako obietnica - krytyka materialna}

MacCormick podziela powszechne intuicje uznające obietnice i umowy za podobne do siebie fenomeny, czemu daje wyraz, zaliczając oba do szerszej kategorii dobrowolnych zobowiązań (voluntary obligations). Chociaż w pewnym momencie stwierdza, że umowy można właściwie rozpatrywać jako obietnice jednego typu (MacCormick, 1972, s. 77), to uznaje je on za zjawiska zasadniczo różne, co uzasadnia poprzez odwołanie się do pojęcia władzy normatywnej (normative power) czy też, bardziej precyzyjnie, reguł przyznających uprawnienia (power-conferring rules). Różnica polega na tym, że w przypadku prób wytłumaczenia mocy wiążącej obietnic, w przeciwieństwie do podlegających egzekucji umów, nie jest niezbędne odwoływanie się do takich reguł. O wiele większą moc eksplanacyjną posiada w ich wypadku inna cecha przyrzeczeń, jaką jest wzbudzanie zaufania (inducing reliance), a konkretnie - możliwość jego wzbudzania u tych, którym te przyrzeczenia składamy. Moc wiążąca obietnic ugruntowana jest zatem, zdaniem MacCormicka, w ogólniejszej regule, mówiącej, że „nie wolno działać tak, żeby zawieść zaufanie innych, kiedy intencjonalnie lub świadomie zachęciliśmy ich do tego, by na nas polegali" 20 (MacCormick, 1972, s. 70; tłumaczenie moje). Istnienie reguł przyznających uprawnienia nie jest więc ani warunkiem koniecznym, ani wystarczającym do tego, by mówić o zobowiązaniach powstałych w wyniku złożenia obietnicy. Zupełnie inaczej jest z umowami, w przypadku których zawierający zgadzają się na ewentualną możliwość przymusowej egzekucji ich dobrowolnie podjętych zobowiązań przez odpowiednie instytucje państwowe, co siłą rzeczy wymaga odwołania się do konwencjonalnego systemu reguł przyznających konkretne uprawnienia konkretnym organom ${ }^{21}$.

Artykuł MacCormicka odbił się w literaturze szerokim echem, wzbudzając zainteresowanie nie tylko prawników, ale również filozofów. Doczekał się wielu głosów polemicznych - w tym bezpośredniej odpowiedzi J. Raza (1972), który starał się udowodnić, że fenomenu obietnicy mimo wszystko nie da się adekwatnie scharakteryzować bez odwołania się do pojęcia władzy normatywnej - jak również szeregu głosów aprobujących, spośród których wiele stanowi kontynuację i rozwinięcie oryginalnych pomysłów MacCormicka.

\footnotetext{
${ }^{20}$,we must not so act as to disappoint the reliance of others when we have intentionally or knowingly induced them to rely upon us" (MacCormick, 1972, s. 70).

${ }^{21}$ Reguły te odnoszą się więc zasadniczo do organów państwa, na przykład sądów, a nie bezpośrednio do zawierających umowy (MacCormick, 1972, s. 77-78).
} 
Wśród nich za najciekawszą uznać należy filozoficzną analizę podstaw prawa kontraktowego zaproponowaną przez D. Kimela ${ }^{22}$ w książce o znaczącym tytule From Promise to Contract (2003).

Kimel wychodzi od podstawowego założenia, że zarówno obietnice, jak i podlegające egzekucji prawnej umowy są narzędziami, dzięki którym jednostki są w stanie lepiej realizować swoją osobistą autonomię, a w konsekwencji prowadzić lepsze życie (Kimel, 2003, s. 126). Zarówno obietnicom, jak i umowom przypisuje więc jednakową wartość instrumentalną (instrumental value). Poza wartością instrumentalną obietnice i umowy posiadają jednak również wartość samoistną (instrinsic value), która w obu przypadkach jest zasadniczo odmienna. O ile bowiem obietnice służą dobrowolnemu wzmacnianiu (zacieśnianiu, czynieniu bardziej wartościowym) relacji międzyludzkich - co skutkuje zwiększeniem osobistej autonomii i w konsekwencji lepszym życiem - o tyle rezultaty umowy są dokładnie przeciwne. Samoistna wartość stojąca za umowami jest bowiem

bardzo różna od tej stojącej za obietnicami [...] Zawiera się ona w ramach, jakich dostarczają nam umowy, a dzięki którym możemy robić pewne rzeczy wspólnie z innymi nie tylko poza siatką już istniejących relacji interpersonalnych, ale również bez wymogu tworzenia podwalin pod takie relacje w przyszłości, bez potrzeby dowiadywania się lub formułowania opinii o osobistych przymiotach innych i bez pozwalania innym na dowiadywanie się i formułowanie takich opinii o nas samych. Jest to, można powiedzieć, wartość osobistego zdystansowania. (Kimel, 2003, s. 78; thumaczenie moje) ${ }^{23}$

Odmienne samoistne wartości stojące za obietnicami i umowami nie sprawiają jednak, że te dwie instytucje się wykluczają. Wręcz przeciwnie: czasami możliwość zawarcia umowy, realizującej samoistną wartość osobistego zdystansowania (personal detachment), w określonym celu, zmniejsza naszą zależność od relacji interpersonalnych, dzięki którym również moglibyśmy takowy cel osiągnąć. Fakt, że bardzo wiele z naszych celów możemy osiągnąć bez polegania na relacjach interpersonalnych, sprawia zaś, iż możemy tworzyć takie relacje z o wiele większą starannością i bez przymusu, co w konsekwencji czyni nasze życie lepszym, bo bardziej autonomicznym. Umowa nie okazuje się zatem czymś całkowicie zależnym od obietnicy, ale raczej jej substytutem (Kimel, 2003, s. 79). Należy też w tym miejscu wspomnieć, że Kimel dopuszcza w pewnych sytuacjach obietnice, które w zasadzie nie służą zacieśnianiu relacji interpersonalnych, oraz umowy, które nie do końca dają się zakwalifikować jako realizujące wartość osobistego oddalenia ${ }^{24}$; są to jednak wyjątki, raczej swego rodzaju anomalie niż przypadki poddające w wątpliwość wartość całej teorii.

\footnotetext{
${ }^{22}$ Będącego, co ciekawe, jednym z uczniów J. Raza.

23 ,very different indeed from that of promise (...) It consists in the very framework contracts provide for doing certain things with others not only outside the context of already-existing relationships, but also without a commitment to the future prospect of such relationships, without being required to know much or form opinions about the personal attributes of others, and without having to allow others to know much and form opinions about oneself. It is, if you like, the value of personal detachment."
}

${ }^{24}$ Klasycznym przykładem takich umów są analizowane przez P. Bensona tak zwane umowy relacjonalne. 
Teoria Kimela, przedstawiona powyżej jedynie w największym zarysie, nie jest oczywiście pozbawiona wad (wiele z wymienionych dalej zarzutów wysuwa Sheinman [2004]). Można zarzucić jej między innymi niezbyt dogłębnie przeprowadzoną analizę pojęcia obietnicy, na którym w dużej mierze bazuje już w części poświęconej samym umowom, oraz powiązanego z nim pojęcia zaufania; nie pokazuje też ona dostatecznie wyraźnie, na czym polegać ma kooperacja umożliwiana przez instytucje zarówno obietnic, jak i umów. Co więcej, wykazanie, że umowy ze swojej istoty nie mogą służyć zacieśnianiu relacji interpersonalnych, nie wystarcza jeszcze, jak zdaje się uważać Kimel, do wykazania, iż realizują one samoistną wartość osobistego zdystansowania. Wydaje się również, że momentami uczeń Raza zbyt nieostro zakreśla granice między „normalnymi” obietnicami, a obietnicami będącymi ,anomaliami”, którym bliżej do umów, i odwrotnie, przez co rozmywa się główna teza jego teorii.

Tego typu zarzutów można by wysunąć więcej25, nie to było jednak celem przywołania koncepcji Kimela. Niezależnie od cechujących ją niedoskonałości, stanowi ona doskonały przykład tego, jak można wykorzystać osiągnięcia filozofii zajmującej się fenomenem przyrzeczeń w teoretycznych rozważaniach nad prawem, nie popełniając jednocześnie błędów zwolenników koncepcji umowy jako obietnicy i „silnej korespondencji” między tymi dwoma pojęciami. Jest to osiągnięcie o tyle wartościowe, że pozwala zachować przynajmniej część naszych potocznych intuicji dotyczących prawa kontraktowego przy jednoczesnym zachowaniu uczciwości intelektualnej wobec trafnych zarzutów formalnej krytyki paradygmatu umowy jako obietnicy. A to niewątpliwie składnia do podjęcia starań w celu sformułowania bardziej rozbudowanej, trafniejszej teorii dotyczącej wzajemnych relacji obietnic oraz podlegających egzekucji umów.

\section{Podsumowanie}

Powyższe rozważania obejmowały jedynie najważniejsze twierdzenia zwolenników paradygmatu obietnicy jako umowy oraz nurtów krytycznych. Przedstawiono tu głównie koncepcje w dużej mierze reprezentatywne dla każdego z tych nurtów - kolejno: Frieda, Gilbert oraz Kimela. Ich analiza została przy tym ograniczona jedynie do takich tez, które miały bezpośredni związek z możliwością aplikacji filozoficznych dociekań dotyczących obietnic na grunt teorii prawa. Wydaje się jednak, że nawet okrojona w ten sposób prezentacja poszczególnych stanowisk, wraz ze wskazaniem na ich mocne i słabe strony, pozwala dojść do wartościowych wniosków dotyczących wzajemnych relacji między obietnicami jako fenomenem moralnym a umowami jako fenomenem prawnym. Przy dużym uznaniu zarówno dla zwolenników koncepcji umowy jako obietnicy, jak i dla ich formalnie usposobionych krytyków, należy dojść do wniosku, że oba te podejścia zbyt upraszczają sprawę - albo nie dostrzegają zasadniczych różnic pomiędzy obietnicą

\footnotetext{
${ }^{25}$ Pominięto tu te zarzuty, które odnosić by się mogły do rozważań Kimela dotyczących bardziej szczegółowych kwestii, jak na przykład kwestia najlepszego teoretycznie reżimu odpowiedzialności prawnej w przypadku niedotrzymania warunków umowy.
} 
a umową, albo, podchodząc do sprawy zbyt formalistycznie, dochodzą do rezultatów sprzecznych z powszechnymi intuicjami, nie oferując w zamian innych zadowalających rozwiązań. Najlepszym wyjściem wydaje się więc „trzecia droga”, reprezentowana przez niektórych materialnie usposobionych krytyków koncepcji umowy jako obietnicy, starająca się połączyć zalety pozostałych stanowisk bez powielania ich błędów. Generalnie mówiąc, odpowiednie podejście do badanego zagadnienia powinno uwzględniać fakt, że obietnice i umowy, mimo wielu łączących je podobieństw - głównie dobrowolności powstałych w ich wyniku zobowiązań, odpowiednio: moralnych i prawnych - są fenomenami odrębnymi, głównie ze względu na występujący w przypadku umów wymóg współzależności uprawnień i obowiązków. Przykładem takiego podejścia może być chociażby oparta na koncepcji sprawiedliwości naprawczej teoria prawa prywatnego zaproponowana przez E. Weinriba (2012a, 2012b), kładąca nacisk właśnie na ową współzależność praw i obowiązków, która charakteryzuje wszystkie gałęzie prawa prywatnego. Analiza tej lub podobnych koncepcji to już jednak temat na inną okazję.

\section{Bibliografia}

Atiyah, P. (1979). The rise and fall of freedom of contract. Oxford, UK: Oxford University Press.

Atiyah, P. (1983). Promises, morals, and law. Oxford, UK: Oxford University Press.

Austin, J. L. (1962). How to do things with words. Oxford, UK: Oxford University Press.

Baier, A. (1985). Promises, promises, promises. W: A. Baier, Postures of the mind (s. 174-206). Minneapolis: University of Minnesota Press.

Barnett, R. (1986). A consent theory of contract. Columbia Law Review, 86(2), 269-321.

Barnett, R. (2014). Contract is not promise; contract is consent. W: G. Klass, G. Letsas, P. Saprai (red.), Philosophical foundations of contract law (s. 42-57). Oxford, UK: Oxford University Press.

Cohon, R. (2008). Hume's morality: Feeling and fabrication. Oxford, UK: Oxford University Press.

Craswell, R. (1989). Contract law, default rules, and the philosophy of promising. Michigan Law Review, 88(3), 489-529.

Craswell, R. (2001). The economic theories of enforcing promises. W: P. Benson, (red.), The theory of contract law: New essays (s. 19-44). Cambridge, UK: Cambridge University Press.

Dyrda, A. (2013). Konwencja u podstaw prawa: Kontrowersje pozytywizmu prawniczego. Warszawa: Wolters Kluwer.

Fried, C. (1981). Contract as promise. Cambridge, MA: Harvard University Press.

Fried, C. (2007). The convergence of contract and promise. Harvard Law Review, 120, 1-9.

Fried, C. (2014). The ambitions of contract as promise. W: G. Klass, G. Letsas, P. Saprai (red.), Philosophical foundations of contract law (s. 17-41). Oxford, UK: Oxford University Press. 
Gilbert, M. (1993). Is an agreement an exchange of promises? Journal of Philosophy, 90(12), 627-649.

Gilbert, M. (2014). Joint commitment: How we make the social world. Oxford, UK: Oxford University Press.

Gilmore, G. (1995). The death of contract ( $2^{\text {nd }}$ ed.). Columbus: Ohio State University Press.

Hume, D. (2007). A treatise of human nature: A critical edition. (D. Fate Norton, M. Norton, red.). Oxford, UK: Oxford University Press.

Ibbetson, D. (1999). A historical introduction to the law of obligations. Oxford, UK: Oxford University Press.

Kennedy, D. (1976). Form and substance in private law adjudication. Harvard Law Review, 89(8), $1685-1778$.

Kimel, D. (2003). From promise to contract. Oxford, UK: Oxford University Press.

Kraus, J. (2001). Reconciling autonomy and efficiency in contract law: The vertical integration strategy. Philosophical Issues, 11, 420-441.

Kraus, J. (2002). Philosophy of contract law. W: J. Coleman, S. Shapiro (red.), The Oxford handbook of jurisprudence and philosophy of law (s. 687-751). Oxford, UK: Oxford University Press.

Kraus, J. (2009). The correspondence of contract and promise. Columbia Law Review, 109(7), 1603-1649.

MacCormick, N. (1972). Voluntary obligations and normative powers (I). Proceedings of the Aristotelian Society, 46, 59-78.

Markovits, D. (2004). Contract and collaboration. Yale Law Journal, 113, 1417-1518.

Markovits, D. (2006). Making and keeping contracts. Virginia Law Review, 92, 1325-1374.

Markovits, D. (2011). Promise as an arm's-length relation. W: H. Sheinman (red.), Promises and agreements: Philosophical essays (s. 295-326). Oxford, UK: Oxford University Press.

Matczak. M. (2007). Summa iniuria: O błędzie formalizmu w stosowaniu prawa. Warszawa: Wydawnictwo Naukowe Scholar.

Penner, J. (1996). Voluntary obligations and the scope of the law of contract. Legal Theory, 2(4), $325-357$.

Pitson, A. (1988). Hume on promises and their obligation. Hume Studies, 14(1), 176-190.

Posner, E. (2011). Contract law and theory. New York, NY: Aspers Publishers.

Pratt, M. (2007). Promises, contracts and promissory obligations. Law and Philosophy, 26(6), $531-574$

Rawls, J. (1955). Two concepts of rules. Philosophical Review, 64(1), 3-32.

Raz, J. (1977). Promises and obligations. W: P. Hacker, Joseph Raz, (red.), Law, Morality, and Society (s. 210-228). Oxford, UK: Oxford University Press.

Raz J. (1972). Voluntary obligations and normative powers (II). Proceedings of the Aristotelian Society, 46, 79-102. 
Scanlon, T. (1998). What we owe to each other. Cambridge, MA: Harvard University Press.

Scanlon, T. (2001). Promises and contracts. W: P. Benson (red.) The theory of contract law: New essays (s. 86-117). Cambridge, UK: Cambridge University Press.

Searle, J. (1964). How to derive 'ought' from 'is'. Philosophical Review, 73(1), 43-58.

Shapiro, S. (2011). Legality. Cambridge, MA: Harvard University Press.

Sheinman, H. (2004). Are normal contracts normal promises? Oxford Journal of Legal Studies, 24(3), 517-537.

Sheinman, H. (2011). Introduction: Promises and agreements. W: H. Sheinman (red.), Promises and agreements: Philosophical essays (s. 3-57). Oxford, UK: Oxford University Press.

Shiffrin, S. (2007). The divergence of contract and promise. Harvard Law Review, 120, 708-753.

Shiffrin, S. (2008). Promising, intimate relationships, and conventionalism. Philosophical Review, $117(4), 481-524$.

Swain, W. (2013). Contract as promise: The role of promising in the law of contract: An historical account. Edinburgh Law Review, 17(1), 1-21.

Weinrib, E. (2012a). The idea of private law. Oxford, UK: Oxford University Press.

Weinrib, E. (2012b). Corrective justice. Oxford, UK: Oxford University Press.

\title{
Between Promise and Contract: The Limits of Application of Philosophical Dis- course on Promises to Theory of Contract Law
}

\begin{abstract}
The concept of promise may be very interesting for legal theorists, especially contract law theorists. The article aims to briefly discuss the issue of promises in contemporary analytic philosophy and show some of its possible applications in legal theory. Three basic approaches will be distinguished: the contract as a promise paradigm (in C. Fried's formulation) and two ways of its critique: formal and material. The contract as a promise paradigm will be rejected as incapable of coping with, among others, the so-called autonomy paradox. Arguments of formally-affected critics will be recognized as basically correct but impossible to be fully accepted because of their formalism. Some propositions of the material critique will be deemed the most promising, despite their incompleteness and numerous errors.
\end{abstract}

Keywords: promise; contract; Fried; autonomy. 